Ann. Biol. anim. Bioch. Biophys., I975, 15 (2), 255-262.

\title{
SYNCHRONIZATION AND INDUCTION OF ESTRUS IN HEIFERS WITH A PROGESTAGEN AND ESTROGEN
}

\author{
J. X. WILTBANK (1) and E. GOXZALEZ-PADILLA ( $\left.{ }^{2}\right)$
}

Texas 4 and II Lniversity and Instituto Nacional de Investigaciones Pecuarias, Mcxico

\section{SUMMARY}

Estrus has been successtully synchronized in cycling heifers and induced in pre-puberal heifers by placing of an implant containing $6 \mathrm{mg}$ of $\mathrm{I} 7$ alpha-acetoxy-I I-beta-methyl ig nor preg + ene 3, 20 dione (norgestomet) in the ear for 9 days and injecting $3 \mathrm{mg}$ of norgestomet and $5 \mathrm{mg}$ of Estradiol Valerate (EV) at time of implantation. In trial I $50 \mathrm{p}$. I 00 of 14 non-cycling control heifers had been in heat after 45 days of breeding compared to 94 p. 100 of 16 treated heifers after + days of breeding. After 45 days of breeding 7 p. roo of the control and 94 p. roo of the treated heifers were pregnant. In the second trial $38 \mathrm{p}$. Too of $8 \mathrm{I}$ non-cycling control heifers had shown heat after 48 days of breeding compared to $79 \mathrm{p}$. 100 in 79 treated heifers after 4 days of brecding. Pregnancy rates after 4,21 , and 48 days of breeding were 4,11 and 27 p. 100 in controls and $+3,58$ and 73 p. Ioo in treated.

Injection of $\mathrm{EV}$ in conjunction with implant and injection of norgestomet in cycling heifers increased heifers in heat by $\mathrm{x} 20$ hours after implant removal from $7+\mathrm{p}$. roo to $95 \mathrm{p}$. Ioo. Injection of $3 \mathrm{mg}$ of norgestomet in conjunction with implant and EV increased the proportion of heifers in heat by 72 hours, after implant removal from $65 \mathrm{p} .100$ to $83 \mathrm{p}$. 100 and by 120 hours after implant removal from $85 \mathrm{p}$. Ioo to $9+\mathrm{p}$. 100 .

In 2 field trials the proportion of heifers showing estrus by 120 hours after implant removal was over $95 \mathrm{p}$. 100 in 5 trials and 85 and $\mathrm{I}$ I p. 100 in the other trials. Pregnancy rate at first service differed by $0,0,4,4,8,2 \mathrm{I}$ and $25 \mathrm{p}$. Ioo. The proportion pregnant after + clays in the treated animals and after $2 \mathrm{I}$ days in the controls differed by $0,3,4$, I, II, I 3 and 2 I p. Ioo.

\section{IN'TRODUC'TION}

A large proportion of cows and heifers do not show estrus the rst 2 I days of the breeding season in beef cattle herds (WiLtBANK et al., I96I; WiltibaNk, I97I ; WiltibaNk, I974; LASTER, I974; Reynoldo, I967 ; Beiliows, I972). Consequently,

(1) Present address: Texas Agr. Exp. Sta., Star Route 2, Box ${ }_{43}$ C Beeville, Texas 78 roz (U. S. A.).

(2) Present address : I. N. I. P., bepartamento de Reproduccion animal, Apartado Postal no $4{ }^{\circ} 652$, Mexico Io, D. F. (Mexique) 
treatments for estrous synchronization which work in the cycling animal are ineffective in a large number of cows and heifers in beef cattle herds. To be effective a treatment regime should synchronize estrus in cycling animals and induce estrus in noncycling animals.

The length of estrous cycle was not altered in many heifers treated in the early stages of the estrous cycle when a treatment regime utilizing an ear implant containing $6 \mathrm{mg}$ of norgestomet and intramuscular injection of $5 \mathrm{mg}$ of estradiol valerate (EV) was used (WILTBANk et al., I975 a). Woody et al., (I967); have shown that injection of large amounts of progesterone early in the estrous cycle decreased the length of life of the corpus luteum and shortened the length of the cycle in the bovine. A treatment regime using this information was developed so corpora lutea in the early stages of the cycle would regress and therefore estrous cycle length would be altered. (Wir.TBANk et al., I975 b).

The purpose of this paper is to summarize briefly the development of a treatment regime for synchronizing estrus in heifers and present the results obtained from using this treatment in cycling and non-cycling heifers.

\section{MATERIALS AND METHODS}

\section{Trial 1}

To determine if estradiol valerate was essential in the treatment regime, cighty-one Angus and Hereford heifers were treated on day $\mathbf{I}$ (day of estrus) $2,3,4,5,6,7$ or 8 of the estrous cycle. All of the heifers were implanted for 9 days with an implant containing $6 \mathrm{mg}$ of norgestomet and received an intramuscular injection of $\mathrm{I} \mathrm{mg}$ of norgestomet. Half of the heifers received an injection of $5 \mathrm{mg}$ of $\mathrm{EV}$ while the others served as controls.

\section{Trial 2}

The value of an intramuscular injection of norgestomet was determined by assigning beef heifers on day I to 5 of the cycle to + treatment groups. All groups received 5 mg of EV at the time of implantation. Two of the groups received one implant while the other 2 groups received two implants. One group receiving one implant and one receiving two implants received an intramuscular injection of $3 \mathrm{mg}$ of norgestomet at the time of implantation.

\section{Trial 3}

The ovaries of a group of yearling heifers were examined rectally for corpora lutca. Heifers with no corpora lutea were divided by breed (Heveford, Heveford-Chavolais Cross or Angus) to either a control group or a group receiving an implant containing $6 \mathrm{mg}$ of norgestomet and an intramuscular injection of $3 \mathrm{mg}$ of norgestomet and $5 \mathrm{mg}$ of EV. Heifers were bred artifically for 45 days. Pregnancy diagnosis was performed at the end of the breeding season and 45 days after the end of the breeding season. More details on experimental procedure is outlined by Gonzalez-Padilla et al., 1975.

\section{Trial 4}

A group of beef heifers in Mexico were checked for estrus for 35 clays and then their ovaries were examined rectally. Heifers not showing cstrus or having corpora lutea were divided into a control group and a group treated as outlined in trial 3 . Heifers were bred artificially for $4^{8}$ days and pregnancy was diagnosed approximately fo days after the end of the breeding period. 


\section{Field trials}

The trials were conducted on farms or ranches throughout the United States. In the first 6 trials heifers were selected by age and weight. It was hoped by this selection to have only cycling heifers on the experiment. Heifers in trial 7 had been checked for estrus for at least 30 days prior to treatment and none of the heifers placed on the trial had been noted in estrus. Heifers were divided by breed, weight and age (when available) into a control group and a group treated as outlined in trial 3 . Heifers were bred artifically for 27 days and pregnancy diagnosis was performed 35 days after the end of the breeding period. Additional details are summarized by SPITzer et al,, (1975).

\section{RESULTS}

\section{Trial 1}

At the time of implant removal only $65 \mathrm{p}$. Ioo of the corpora lutea had regressed $\mathbf{n}$ heifers treated on day I to 4 of the cycle with the implant and injection of norgestomet while $86 \mathrm{p}$. Ioo of the corpora lutea had regressed in the heifers treated with the implant and injection of norgestomet and EV (table I). Similar differences were

TABLE I

Effect of injection of estradiol valerate on regression of corpora lutea and estrous synchronization

\begin{tabular}{|c|c|c|c|c|}
\hline Stage of the cycle & Treatment & No Heifers & $\begin{array}{c}\text { C. L. } \\
\text { Regressed }\left({ }^{3}\right) \\
(\%)\end{array}$ & $\begin{array}{c}\text { Showing estrus by } \\
120 \text { hours after } \\
\text { implant removal }(\%)\end{array}$ \\
\hline Day 1-'t & $\begin{array}{l}I+I M I(1) \\
I+I N I+E V(2)\end{array}$ & $\begin{array}{l}20 \\
22\end{array}$ & $\begin{array}{l}65 \\
865\end{array}$ & $\begin{array}{l}75 \\
91\end{array}$ \\
\hline Day 5-8 & $\begin{array}{l}I+I N I(1) \\
I \div I N I+E V\left({ }^{2}\right)\end{array}$ & $\begin{array}{l}19 \\
20\end{array}$ & $\begin{array}{l}32 \\
86)\end{array}$ & $\begin{array}{r}7 t \\
100\end{array}$ \\
\hline
\end{tabular}

(1) 1 implant of $6 \mathrm{mg}$ of norgestomet for 9 days +1 injection of $1 \mathrm{mg}$ of norgestomet.

(2) Same as 1 except $5 \mathrm{mg}$ of $\mathrm{EV}$ at time of implantation.

(3) Regressed at time of implant removal.

noted in heifers treated on day 5-8 of the cycle. The percentage of heifers showing estrus by 120 hours after implant removal was 75 and $74 \mathrm{p}$. IoO in heifers which did not receive an injection of $\mathrm{EV}$ compared to $9 \mathrm{I}$ and Ioo $\mathrm{p}$. Ioo in heifers receiving the $\mathrm{EV}$. Therefore, $\mathrm{EV}$ appeared to be an important ingredient of the treatment regime.

\section{Trial 2}

The differences in the proportion of heifers showing estrus by 120 hours after implant removal were small in heifers receiving one implant versus those receiving 
two implants (table 2). More heifers receiving the injection of norgestomet were in heat at $48,72,96$ and 220 hours after implant removal than in those receiving no norgestomet.

\section{TABLE 2}

Effect of number of implants and injection of norgestomet on synchronization (1)

\begin{tabular}{|c|c|c|c|c|c|c|c|}
\hline \multirow{2}{*}{ No Implant } & \multirow{2}{*}{ I.II Injection } & \multirow{2}{*}{ No Heif } & \multicolumn{5}{|c|}{ Showing estrus (Hours after implant removal) } \\
\hline & & & $\ddot{\prime \prime}^{\prime}$ & 48 & 7.1 & 96 & $1 \geq 11$ \\
\hline 1 & $\mathrm{EV}(\mathbf{2})$ & 20 & 11 & 35 & 6ij & 70 & 85 \\
\hline 1 & $\mathrm{EV}+$ Norgestomet $\left({ }^{3}\right)$ & 18 & 11 & (j) & 83 & $9^{\prime}$ & $9_{t}^{\prime}$ \\
\hline 2 & $\mathrm{EV}$ & 19 & 5 & 21 & 5s & $7 \mathbf{t}^{\prime}$ & $8 !$ \\
\hline 2 & $\mathrm{EV}+$ Norgestomet & 19 & $\bar{j}$ & 42 & ti3 & 79 & 95 \\
\hline
\end{tabular}

(1) All heifers day 1-5 at time of treatment.

(2) $5 \mathrm{mg}$ of $\mathrm{EV}$ at time of implantation.

$\left({ }^{3}\right)$ Same as 2 plus $3 \mathrm{mg}$ of norgestomet at time of implantation.

\section{Trial 3}

None of the control heifers had shown estrus after 2 I days of breeding and only 7 had shown estrus after 45 days of breeding while $I_{5}$ of 16 treated heifers had shown estrus after 4 days of breeding (table 3 ). Thus this treatment regime appeared to induce estrus in prepuberal heifers. The estrus appeared to be fertile as 8 out of I 5 heifers bred at the induced estrus became pregnant.

TABLE 3

Induction of puberty in prepuberal heifers

(Colorado)

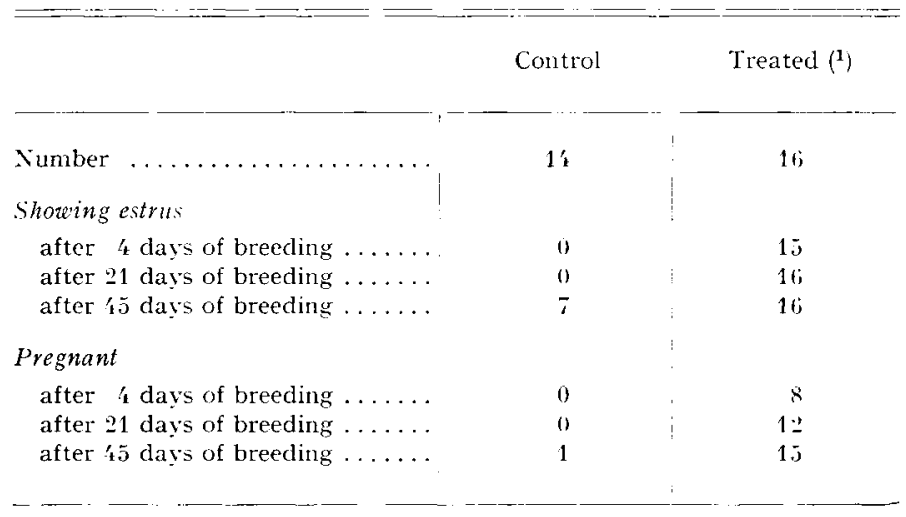

(1) $6 \mathrm{mg}$ of norgestomet for 9 days $+\mathrm{IM}$ injection of $5 \mathrm{mg}$ of estradiol valerate and $3 \mathrm{ng}$ of norgestomet at the time of implantation. 


\section{Trial 4}

Thirty-eight percent of the control heifers had shown estrus and $27 \mathrm{p}$. roo had become pregnant after 48 days of breeding (table 4 ), while $79 \mathrm{p}$. Ioo of the treated heifers had shown estrus after 4 days of breeding, and 43,58 and $73 \mathrm{p}$. roo became pregnant after $4,2 \mathbf{I}$ and 45 days of breeding, respectively. The ability of the treatment to induce estrus appeared to be related to weight of the heifers at the time of treatment (GoNZALEZ-PADILLA et al., I974).

TABLE 4

Induction of puberty in prepuberal heifers

(Mexico)

\begin{tabular}{|c|c|c|}
\hline ! & Control & Treated (1) \\
\hline Number & 81 & 77 \\
\hline Showing estrus $(\%)$ & & \\
\hline $\begin{array}{l}\text { after } 4 \text { days of breeding } \ldots \ldots \\
\text { after } 21 \text { days of breeding } \ldots \ldots \ldots \\
\text { after } \$ 8 \text { days of breeding } \ldots \ldots \ldots\end{array}$ & $\begin{array}{r}6 \\
28 \\
38\end{array}$ & $\begin{array}{l}79 \\
81 \\
81\end{array}$ \\
\hline Pregnant $(\%)$ & & \\
\hline $\begin{array}{l}\text { after } 4 \text { days of breeding } \ldots \ldots \\
\text { after } 21 \text { days of breeding } \ldots \ldots \ldots \\
\text { after } 48 \text { days of breeding } \ldots \ldots \ldots\end{array}$ & $\begin{array}{l}: \\
11 \\
27\end{array}$ & $\begin{array}{l}13 \\
58 \\
73\end{array}$ \\
\hline $\begin{array}{l}\text { Anestrous after } 1 \text { st observed es- } \\
\quad \text { trus }(\%) \ldots \ldots \ldots \ldots \ldots \ldots \ldots\end{array}$ & 13 & 6 \\
\hline
\end{tabular}

( $\left.{ }^{1}\right) 6 \mathrm{mg}$ of norgestomet for 9 days $-\mathrm{IMI}$ injection of $5 \mathrm{mg}$ of estradiol valerate and $3 \mathrm{mg}$ of norgestomet at the time of implantation.

\section{Ficld trials}

The ability of the treatment regime to control the estrous cycle and induce estrus can be seen by comparing the proportion of treated heifers showing estrus by 5 days after implant removal to the proportion of controls showing estrus by 27 days after implant removal. In all 7 trials the proportion of treated heifers either exceeded or was equal to the proportion of controls (table 5). Thus the treatment regime appeared capable of controlling the estrous cycle and inducing estrus in some but not all of the prepuberal heifers.

Fertility at the synchronized estrus was not different from that noted in the controls at Ist service in 4 of the 7 trials (table 6). However, in 3 trials ( 1,4 and 7 ) fertility was markedly lower. In trial $I$, one of the 2 technicians involved had not previously bred heifers and consequently had a difficult time breeding heifers during the synchronized period. The proportion of heifers conceiving at ist service in the 
TABLE 5

Heifers showing estrus in seven ficld trials

\begin{tabular}{|c|c|c|c|c|c|c|c|c|}
\hline \multirow{3}{*}{ Trial } & \multirow{2}{*}{\multicolumn{4}{|c|}{ Nimbec }} & \multicolumn{4}{|c|}{ In estrus by } \\
\hline & & & & & \multicolumn{2}{|c|}{$\begin{array}{l}5 \text { days } \\
\text { after implant removal }(\%)\end{array}$} & \multicolumn{2}{|c|}{$\begin{array}{l}\qquad 7 \text { days } \\
\text { after implant removal }\left(\begin{array}{l}0 \\
0\end{array}\right)\end{array}$} \\
\hline & 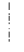 & Control & $!$ & Treated (1) & Control & Treated (1) & Control & Treated $(1)$ \\
\hline 1 & . & 77 & & 78 & 27 & 1000 & 100 & 1001 \\
\hline 2 & 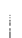 & 95 & & 98 & 97 & 98 & $9 ?$ & $9=$ \\
\hline 3 & i & 53 & & 56 & 28 & 98 & 96 & 1001 \\
\hline 't & & 39 & & 39 & 111 & 8.5 & 7 & 98 \\
\hline 5 & ' & 99 & & 94 & $\because 4$ & 96 & 93 & 1011 \\
\hline i; & . & 99 & & 99 & $\geq 6$ & 94 & $9: 2$ & 99 \\
\hline 7 & | & 89 & & 97 & 16 & 77 & 46 & 811 \\
\hline
\end{tabular}

(1) Implant containing 6 mor of norgestomet for 9 day's and an I.M injection of $6 \mathrm{mg}$ of estradiol valerate $3 \mathrm{mg}$ of norgestomet.

\begin{tabular}{|c|c|c|c|c|c|c|c|c|}
\hline \multicolumn{9}{|c|}{ Heifers pregnant in seven ficld trials } \\
\hline \multirow{3}{*}{ Trial } & \multicolumn{8}{|c|}{ Pregnant } \\
\hline & \multicolumn{2}{|c|}{$\begin{array}{c}\text { After } 15 t \\
\text { Service }(\%)\end{array}$} & \multicolumn{2}{|c|}{$\begin{array}{c}\text { After 't dars } \\
\text { of breeding }(\%)\end{array}$} & \multicolumn{2}{|c|}{$\begin{array}{c}\text { After } 21 \text { days } \\
\text { of breeding }(\%)\end{array}$} & \multicolumn{2}{|c|}{$\begin{array}{l}\text { After } 27 \text { days } \\
\text { of breeding }(\%)\end{array}$} \\
\hline & Control & Treated $(\mathbf{l})$ & Control & Treated $(1)$ & Control & Treated $(\mathbf{l})$ & Control & Treated (1) \\
\hline 1 & $5^{\prime} t$ & 33 & 14 & 33 & $5^{\prime} t$ & $5: 3$ & 6il & bil \\
\hline$\underline{2}$ & 63 & $6: 3$ & 10) & 63 & 711 & 70 & $7 t_{t}^{\prime}$ & 80 \\
\hline 3 & 60 & 56 & 15 & 5.5 & $5 n$ & $i_{t}^{\prime}$ & Gít & 71 \\
\hline$\epsilon_{t}^{\prime}$ & 6.3 & $3 s$ & ; & 31 & $4 '$ & $3 \mathrm{~N}$ & 51 & 51 \\
\hline 5 & 45 & 49 & 15 & 43 & 47 & 54 & 50 & 56 \\
\hline 6 & 45 & 45 & 15 & 43 & $4: 3$ & 保 & 50 & 56 \\
\hline 7 & $5:$ & $\therefore 1$ & $i$ & 311 & $1 !$ & $3_{t}^{\prime}$ & 26 & :3 \\
\hline & & & & & & & & \\
\hline
\end{tabular}

(1) Implant containing $6 \mathrm{mg}$ of norgestomet for 9 days and an IM injection of $6 \mathrm{mg}$ of estradiol valerate and $3 \mathrm{mg}$ of norgestomet. 
treated and control animals differed markedly for this technician while little difference between treated and controls were noted for the other technician. Similar results were experienced for 2 technicans in trial 7 were one had been recently trained and had bred only a limited number of animals prior to the trial. In trial 4 the technican had not done any breeding since last breeding season and became tired during the synchronized period. Therefore, it is thought that the poor results in the treated animals noted for trial $I, 4$ and 7 could be the result of technician efficiency rather than treatment regime.

To be useful a treatment regime should provide a method so that the proportion of treated heifers pregnant after 4 days of breeding would be equal to or exceed that noted in the controls after $2 \mathrm{I}$ days of breeding. In two trials ( $I$ and 4 ) the difference in the proportion pregnant after $2 \mathrm{I}$ days in the control animals exceeded the proportion pregnant after 4 days by $2 \mathrm{I}$ and $\mathrm{I} 3 \mathrm{p}$. IOo $(\mathrm{P}<.05)$. Non-significant differences of $7,3,4$ in favor of control animals were noted in trial 2, 3 and 5, respectively $(\mathrm{P}<.05)$. No difference was noted in trial 6 and a difference of II $\mathrm{p}$. Ioo in favor of the treated animals was seen in trial $7(\mathrm{P}<.05)$.

The results indicate the ability of the treatment regime to synchronize estrus in cycling animals without a marked decrease in fertility. The treatment also had ability to induce estrus in some prepuberal heifers without a marked reduction of fertility. However, the limitations of this treatment in the prepuberal heifers need to be identified more accurately.

Colloque : Control of sexual cycles in domestic animals October 27-30, 1974, Nouzilly.

\section{RÉSUMÉ}

\section{SYNCHRONISATION ET INDUCTION DE L'GESTRUS \\ CHEZ LES GÉNISSES A L'AIDE D'UN PROGESTAGÈNE ET D'UN GESTROGÈNE}

L'œestrus a été synchronisé avec succès chez des génisses cycliques et induit chez des génisses prépubères en plaçant un implant contenant $6 \mathrm{mg}$ de norgestomet dans l'oreille pendant 9 jours et en injectant $3 \mathrm{mg}$ de norgestomet et $5 \mathrm{mg}$ de valérate d'œestradiol au moment de la pose de l'implant.

Dans l'essai I, 50 p. roo des I 4 génisses témoins non cycliques ont été en chaleur après 45 jours de mise à la reproduction contre $94 \mathrm{p}$. Ioo des 16 génisses traitées dans les 4 jours qui suivent le retrait de l'implant. Après 45 jours de mise à la reproduction, $7 \mathrm{p}$. Ioo des génisses témoins étaient gestantes alors que ce taux était égal à 94 p. Ioo chez les génisses traitées.

Dans l'essai $2,3^{8}$ p. Ioo des 8 I génisses témoins non cycliques ont été détectées en chaleur dans les 48 jours qui suivent la mise à la reproduction; ceci est à comparer aux 79 p. Ioo des 79 génisses traitées dans les 4 premiers jours. Les taux de gestation après 4,21 et 48 jours de mise à la reproduction ont été de 4 , I I et $27 \mathrm{p}$. Ioo chez les génisses témoins et 43,58 et 73 p. Ioo chez les génisses traitées.

L'injection de valérate d'ostradiol, en plus de la pose d'un implant et de l'injection de norgestomet chez des génisses cycliques augmente la proportion de génisses en chaleur dans les I 20 heures qui suivent la fin du traitement de $74 \mathrm{p}$. roo à $95 \mathrm{p}$. Ioo. L'injection de 3 mg de norgestomet en plus de la pose d'un implant et de l'injection de valérate d'œstradiol augmente la proportion de génisses en chaleur dans les 72 heures qui suivent la fin du traitement de 65 p. Ioo à 83 p. Ioo et dans les r2o heures de 85 p. Ioo à 94 p. Ioo.

Dans les 5 essais sur le terrain, la proportion de génisses en chaleur dans les I 20 heures qui suivent le retrait de l'implant était supérieure à $95 \mathrm{p}$. Ioo dans 5 essais et à 85 et I I p. roo dans l'autre. Les taux de gestation au premier service différaient de $0,0,4,4,8,2$ I ct 25 p. Ioo par rapport aux 
témoins dans chacun cles essais. Les proportions de génisses gestantes après 4 jours chez les animaux traités et après $2 \mathrm{I}$ jours chez les témoins différaient de $0,3,4, I, I I, I 3$ et $2 I$ p. I 00 en faveur des animaux traités.

\section{REFERENCES}

Bellows R. A., I972. Factors affecting losses at calving. In improving reproductive efficiency in Beef cattle. Proceed. 21st and 22nd Texas Beef Cattle Short Course, I65.

Gonzalez-Padilla E., Ruiz R., Lefever D., Denham A., Wiltbank J. N., I975. Puberty in Beef heifers. III. Induction of fertile estrus. (To be published).

Laster D. B., I974. Sources and causes of conception losses in the cow. Proceed. 8th Conf. on Artificial Insemination of Beef Cattle.

Reynolds W. L., I972. Breeds and reproduction. In Factors affecting Calf crop. Univ. Fla. Press, 244.

Spitzer J. C., Jones D. L., Miksch E. D., Wiltbank J. N., I975. Synchronization of estrus in Beef cattle. V. Field trials in heifers. (To be published).

Wiltbank J. N., I971. How to increase Beef A. I. in the I970's. N. A. A. B., 22th Convention, 206.

WiLtbank J. N., I974. Management programs to increase reproductive efficiency of Beef herds. $J$. Anim. Sci., 38, Suppl. I, 58 .

Wiltbank J. N., Burrela C., Deyoung J., Lefever D. G., i975a. Estrous synchronization in Beef cattle. I. Use of an ear implant containing Norgestomet and injection of estradiol valerate in heifers. (To be published).

Wiltbank J. N., Slade B., Morris L. E., Lefever D. G., I975 $b$. Estrous synchronization in Beef cattle. III. Modification of ear implant and estradiol valerate treatment by injection of a progesten in heifers. (To be published).

Wiltbank J. N., Warwick E. J., Vernon E. H., Priode B. M., Ig6r. Factors affecting net Calf crop in Beef cattle. J. Anim. Sci, 20, 409.

Woody C. O., First W. L., Pope A. L., 1967. Effect of exogenous progesterone on estrous cycle length. J.Anim. Sci, 26, 139-14r. 